This item was submitted to Loughborough's Research Repository by the author.

Items in Figshare are protected by copyright, with all rights reserved, unless otherwise indicated.

\title{
Foucault, democracy and the ambivalence of rights
}

PLEASE CITE THE PUBLISHED VERSION

https://doi.org/10.1080/13698230.2017.1369627

\section{PUBLISHER}

Taylor and Francies

\section{VERSION}

AM (Accepted Manuscript)

\section{PUBLISHER STATEMENT}

This is an Accepted Manuscript of an article published by Taylor \& Francis in Critical Review of International Social and Political Philosophy on 06 Sep 2017, available online:

https://doi.org/10.1080/13698230.2017.1369627

\section{LICENCE}

CC BY-NC-ND 4.0

\section{REPOSITORY RECORD}

Aitchison, Guy. 2019. "Foucault, Democracy and the Ambivalence of Rights". Loughborough University. https://hdl.handle.net/2134/15059805.v1. 


\title{
Foucault, democracy and the ambivalence of rights
}

\author{
Dr. Guy Aitchison \\ g.aitchison@lboro.ac.uk
}

Keywords: Foucault, rights, citizenship, liberalism, democracy, Wendy Brown

Pre-publication draft.

Publication date 2019/9/19

Critical Review of International Social and Political Philosophy

Volume 22 Issue 6

DOI: $10.1080 / 13698230.2017 .1369627$

Foucault and the Politics of Rights, by Ben Golder, Stanford, Stanford University Press, 2015, 260 pp; Undoing the demos: Neoliberalism's Stealth Revolution, by Wendy Brown, Massachusetts MIT Press, 2015, 296 pp.

According to the perspective of some radicals, the project of critique demands rejection - not only of the dominant conceptions of legitimacy and justice - but of the values, categories and forms of subjectivity that organise them. This form of critique seems to call into question not only liberalism, but the very aspiration to universality of humanist thinking and the project of modernity itself (Agamben, 1998). Others argue that while liberal citizenship does not exhaust the aspirations of emancipatory politics, and is rife with contradictions and exclusions, it nonetheless provides a defence against arbitrary power that is intrinsically valuable, linked to the free and equal status of human beings (Fraser, 1989). Others still take a more instrumental approach that falls somewhere in between these two. According to this perspective, liberal rights and norms are useful but they are to be kept at arm's length, being selectively deployed against the status quo with the aim of expanding the possibilities for human development in ways unauthorised by a liberal regime (Rancière, 2015).

Two recent books in critical theory offer the chance to reflect on the utility, as well as the possible risks and limitations, of liberal rights and citizenship in resisting contemporary forms of power. While Ben Golder's book 'Foucault and the Politics of Rights' offers a compelling reconstruction 
of Foucault's thought that calls attention to the ambivalent character of rights discourse, Wendy Brown's book 'Undoing the Demos' applies a Foucaudlian mode of analysis to paint a dark vision of how neoliberalism is reconfiguring liberal-democratic institutions and norms according to economic imperatives. The main thrust of Golder's work is to situate Foucault within the third more instrumental radical orientation I identified, rather than the first more revolutionary camp where he is often located by critics and followers alike. Golder's work offers the most extensive analysis yet of Foucault's thinking on rights. While many readers will be familiar with the French philosopher's more critical insights into how rights operate as a mode of power, fewer will be familiar with the more constructive implications of his analysis which prompt us to consider what new alternative forms of subjectivity rights might call into being. Part of the originality of Foucault's approach, for Golder, is in seeing rights claims as a vehicle for forging new emancipated forms of personal identity.

In her own analysis, meanwhile, Brown suggest that while Foucault offers a fruitful set of tools for dissecting how economic liberalism functions as a mode of rule he is insufficiently interested in the political side of the liberal project. Foucault's emphasis on an ethics of personal transformation, she argues, came at the expense of thinking about the forms of collective democratic politics necessary for effective resistance. Under neoliberalism, she argues, economic values have so thoroughly penetrated the public sphere that long-standing norms of participation, deliberation and equal rights have become distorted and toothless. Whereas Brown's previous writings have focused on rights as an aspect of domination, implicated in the spread of market-friendly subjectivities and the management of subordinate identities, in this work rights figure primarily as something we stand to lose with the anti-democratic proliferation of market norms and principles (2004).

In this review essay, I unpack the arguments of these two books, situating them within a broader context of critical thought and evaluating some of their central ideas and assumptions. In Section 1, I examine the nature of Foucault's critique of classical understandings of liberal rights before turning in Section 2 to reflect on what is distinctive and valuable about his own approach understood, in Golder's terms, as a 'critical conduct of rights' that deploys rights in a 'tactical' way against a liberal order. In Section 3 I suggest that while Golder provides an admirable exposition of Foucault's thought, he is insufficiently critical of this central notion of an anti-foundational tactical conception of rights which is morally dubious and risks being incoherent. Instead of seeing rights as tactical, I suggest, it is better to see them as 'political' in being open to ongoing revision and contestation while nonetheless deriving from moral values. In Section 4, I examine how Foucault's thinking has informed a recent critical literature on rights and human rights, situating the influential 
critiques of rights by Brown within this literature. I then turn in Section 5 to consider Brown's most recent analysis of how liberal rights and citizenship are being reconstituted by the aggressive extension of market principles into the public sphere. I conclude in Section 6 with some reflections on where rights figure in the project of radical critique.

\section{The nature of Foucault's critique}

In 'Foucault and the Politics of Rights', Golder sets out to address the perplexing tension between Foucault's early critical genealogies, in which rights discourse figures primarily as an aspect of disciplinary power, and his later appeal to specific rights for prisoners, gays, and asylum-seekers in his interviews, articles and activism. Faced with the exigencies of practical advocacy and the need to condemn domination, did Foucault come to appreciate the need for universal moral categories? Or did he somehow maintain the critical scepticism that had characterised his earlier dissection of liberal norms and institutions? Golder decisively rejects the idea of some fundamental shift in Foucault's work. He sets out to refute a self-assured liberal reading which says that Foucault's later use of rights represented a retreat from the radical iconoclasm of his earlier work with its thoroughgoing scepticism towards universal categories and - it might seem - towards any form of propositional politics.

According to the interpretation Golder rejects, Foucault's later use of rights signalled a partial reconciliation with the liberal political order he had previously disavowed (Wolin, 2006; Paras, 2006). This interpretation neatly fits Foucault within the 'humanistic turn' among radical French intellectuals in the 1970's which followed the dramatic revelations about the brutalities of the gulags by Soviet dissidents who articulated their opposition to totalitarianism in the language of human rights. As the philosopher Claude Left put it, these developments had 'a most disturbing effect' on the radical left in France since 'rights no longer seem to be formal, intended to conceal a system of domination; they are now seen to embody a real struggle against oppression' (Horvath, 200, p. 901). Rather than positing some basic ideological realignment, Golder calls attention to the continuities in Foucault's thinking. His analysis aims to show how Foucault's critical interrogation of humanistic categories informed his later 'tactical' use of rights discourse.

In his earlier historical work, Foucault offered an incisive account of the rise of the modern 'disciplines' - the forms of scientific knowledge that organise human behaviour in prisons, psychiatric units and other institutional regimes - which called into question two assumptions about 
sovereignty and subjectivity integral to classical liberal understanding of rights (Foucault, 2012). Under the traditional liberal understanding, rights are understood primarily as defences against power that define a protected perimeter of freedom in which the state cannot intrude. Here, rights serve primarily a negative, checking function that repels potential incursions, as captured in the various spatial metaphors used to describe rights in liberal theory, as a form of 'property' or as 'side-constraints' (Nozick, 1974, pp. 33-35). The central thrust of Foucault's work shifted the locus of modern power from the 'juridical' seat of sovereignty in the state to the shifting, pervasive forms of power across the entire domain of social relations. As Foucault himself provocatively put it, his approach aimed to 'cut off the head of the king' in political theory, redirecting attention from the state to minute everyday mechanisms - the 'micro-physics of power' - through which compliance is reproduced (Foucault, 1980, p. 121). The implication was that the traditional conception of rights as protections against state power - risked leaving these forms of domination untouched.

The second significant implication of Foucault's analysis was to call into question the classical liberal understanding of political subjects as intentional agents who confront power as something external. Again, the classical liberal view tends to conceive of rights-bearers as autonomous individuals who independently choose their course through life, shaping their own identity and behaviour within a protected domain of legal freedoms. For Foucault, the idea of a pre-discursive 'choosing' self at the heart of liberal rights discourse served only to naturalise a certain historically contingent type of individual. While presenting itself as neutral and ahistorical, the regime of rights exerts a normalising pressure on those subject to it, shaping their thoughts, behaviour and desires according to a conception of personhood congruent with dominant power. As Foucault put it in his 'Two Lectures' in 1976, the 'system of right, the domain of the law, are permanent agents of these relations of domination, these polymorphous techniques of subjugation' (Foucault 1980, p. 96). Here, rights are not simply defences against power, but a crucial mechanism through which power is reproduced. Thus, by appealing to rights, we may inadvertently strengthen the very forms of power that keep us subdued.

Nonetheless, from the mid-1970s onwards, Foucault made reference to rights in his essays, interviews and activism, defending traditional rights to due process and supporting the rights of specific groups, such as prisoners, gays and asylum-seekers. In a plea at the United Nations for assistance for the displaced Vietnamese 'boat people', Foucault even asserted a new 'right of the governed' to take action independently of states in the international arena, arguing that the 'will of individuals must make a place for itself in a reality of which governments have attempted to reserve a monopoly for themselves' (Foucault 2000, pp. 474-475). In this call for 'international citizenship', 
rights no longer figure as an instrument of rule, but as a means to assert the 'will of individuals' against state power. What, if anything, had changed?

\section{A 'critical conduct' of rights}

Golder argues that Foucault's use of rights did not amount to a rejection of his earlier, radical critique of the ontology of the liberal subject and juridical modes of sovereignty. For Golder, Foucault's over-riding concern was not with rights as such, but with the depoliticising associations of the discourse which risked closing the boundaries of freedom in advance based on a narrow account of what it means to be human. Foucault's concern was to use forms of rights in a 'tactical' way, drawing from the discursive resources of the existing historical milieu in order to challenge and subvert disciplinary power. Intriguingly, Foucault offered past examples of such an approach in the form of the ascetics, mystics and eschatological communities of medieval Christendom who radicalised the tenets of orthodoxy to legitimise new modes of individual and collective life (Golder 2015, pp. 56-58).

In one of the most interesting and original parts of the book, in Chapter 4, Golder demonstrates how Foucault's approach shaped his thinking about two issues of contemporary political concern: assisted suicide and the death penalty. Whereas liberals have typically defended a right to assisted suicide as a matter of individual autonomy in line with accepted ideas about the prevention of unnecessary suffering (Ronald Dworkin et al, 1997), Foucault discussed the decision to end one's life as an act of social transgression and rebellion against 'bio-political' rule. According to this picture, the subject of rights is understood not as a passively suffering 'patient' (in a manner that risks strengthening the control of medical authorities) but as a potential agent of social disruption. By contrast, when it came to the death penalty, Foucault did not rely upon an appeal to rights, instead focusing on the entire system of penal incarceration as a system of racial domination (Golder, pp. 132-135).

In response, it might be queried to what extent this is truly an alternative to an autonomy-focused approach to rights, rather than a complementary perspective (surely modern power still operates through the coercion of individual options?) and the prospect of drug-fuelled 'suicide festivals and orgies' may not be to everyone's taste (133). Nonetheless, the broad approach is compelling. Foucault - or Golder's Foucault - appears to be saying, 'Do not to think of a right merely as a way of enhancing choice within existing structures, but consider instead the types of world it might call into being and the possibilities it offers to reimagine ourselves'. Instead of rights being a pathway 
for including minorities within mainstream structures, they become a means to forge new subjects that in turn unsettle established identities. This emphasis on subversion is combined with a justified caution about how the institutionalisation of rights can inadvertently empower external agents who assume the paternalistic role of protector.

Notably, Golder is not the first to provide a sympathetic reconstruction of Foucault's thinking on rights that recognises the basic continuities in his thought. Paul Patton, for example, concurs that Foucault belongs in the category of ambivalent sceptics, arguing that Foucault endorses 'forms of right that already operate in our present and that are capable of providing effective counterarguments to the techniques and goals of disciplinary power' (2005, p. 283). However, 'Foucault and the Politics of Human Rights' must qualify as the most comprehensive, authoritative presentation of this position to date. Golder's exegesis is also admirably clear and he does an excellent job of setting out Foucault's occasionally ambiguous propositions in a clear and systematic way.

\section{Rights: political, not tactical}

Nonetheless, while I find the overall approach congenial - and have little to disagree with in Golder's interpretation of Foucault - I was not entirely convinced by the key notion of a purely 'tactical' approach to rights and I think Golder may be over-stating just how original this kind of approach really is. Golder has a good stab at defining what he means by a tactical rights politics. It means using rights as a 'tool', an 'instrument' or even a 'truth weapon' (97). To use rights tactically, is to use rights in a way that does not 'conform to the function allocated to rights within the prevailing terms of engagement' and to deploy them outside the 'extant parameters of a liberal system (of law and state)' (28).

If this is what is meant, it is not so clear this represents a radical break with past 'liberal' struggles over rights - or, perhaps more accurately, those struggles that have been retrospectively assimilated to the liberal corpus. Using rights to attack power in a way that departs from established usage has been an established feature of the historical practice of rights since its earliest deployment as a rhetorical tool for attacking 'tyrannical' government. Over the course of the 18th and 19th centuries, radical and working class movements struggled for rights to political participation, free speech, education and decent working conditions (Ishay, 2008). In applying rights to sites and subjects previously marked as 'private', 'social' and 'apolitical', these struggles were radically discontinuous with prevailing notions of the term, highlighting the hypocrisies, contradictions and 
exclusions of the liberal establishment. If there is any difference, it seems to be in Foucault's more uneasy relationship to the underlying moral and empirical claims about individuals that have traditionally accompanied such struggles.

Alternatively, then, using rights tactically might mean maintaining a certain critical distance from the concept; not buying into the whole story about human beings and their needs that is supposed to go along with it. This would seem to follow from the scepticism towards 'totalising' theories and Golder's claim that a tactical posture involves not ascribing any 'ultimate value' to rights (112). Foucault himself denied that freedom is the subject's 'essence' and 'destiny' (112). Yet there is a degree of ambiguity here. If by 'ultimate value', it is meant that rights are not Platonic truths, in the sense of being 'timeless', 'self-evident' notions given to us by nature or reason then that is something most contemporary theorists of rights would happily go along with.

John Searle once suggested that the biggest mistake of the classical metaphysicians was not to think that they had found some metaphysical foundation - some Archimedian point - to validate their claims about the world, but to think that you needed one and that something vital would be lost without it. In the absence of such a rock-hard foundation, the 'game' carries on regardless: it remains possible to advance general truth claims and to disagree meaningfully with one another about knowledge and ethics from within the world of human values and experience (1983).

It can seem as though post-structuralist critics of rights commit a parallel error in assuming that by exposing the lack of any 'ultimate' metaphysical foundations for rights they have radically thrown into question the whole project. To be clear, I am not saying that Golder's view is as crude as this. Nonetheless, it would help to have some indication of who Golder takes the main antagonist of Foucault's position to be. There are still, it should be said, residual traces of classical metaphysical thinking in the approach of some liberal philosophers who contemplate rights in wholly abstract moralistic terms divorced from politics (Finnis, 2011; Gewirth, 1982).

However, there is now considerable agreement among philosophers that theories of rights and human rights should be 'political' in some relevant sense, although how exactly is far from settled (Valentini, 2012). The dominant mode of political analysis has focused on the official regime of human rights as contained in international law, setting out the role of human rights as standards of legitimacy in international affairs. The most systematic account of this kind has come from Charles Beitz who interprets human rights on the basis of a descriptive account of their role in setting 
standards for state action and intervention within the international regime of human rights law and institutions that emerged following World War Two (Beitz, 2011).

Like Foucault and his followers, this type of account stresses that rights are a political achievement, but it differs markedly in focusing almost entirely on setting limits to state sovereignty and in interpreting human rights claims based on the textual formulations of international law. A central difficulty with this sovereignty-focused approach is that it privileges one particular function of human rights - as a set of institutional norms that regulate international relations - above the other roles they play in politics. It would therefore appear to presuppose precisely what is at issue in making our understanding of rights depend on the role assigned to them within a system of institutions and laws they exist in no small part to criticise.

A more promising 'bottom-up' approach - inspired by the writings of Hannah Arendt and expounded by the likes of James Ingram - focuses on the dynamic, contestable character of human rights (Ingram, 2008). According to this view, human rights are universal norms that are subject to continuous revision and reinterpretation as previously excluded groups lay claim to the flexible ideal of a shared humanity. Here, human rights are political in the sense of being open, provisional, and subject to ongoing political challenge. According to this approach, human rights are understood as universal norms - but not in some fixed, ahistorical sense that would place them beyond effective contestation. Rather, they are universal in the sense of being claimable by any potential political subject. This position does not deny that our present conception of rights invariably contains silences, exclusions and omissions, but it nonetheless acknowledges the genuine improvements in freedom it offers relative to traditional, hierarchical conceptions of human society and holds out the possibility of future innovations.

We might say that universalism here is understood not merely as a noun, but as a verb. Part of the value of human rights comes from the fact that they are intrinsically universalisable being open to contestation by dominated, exploited and excluded groups. This focus on the politics of 'claiming' rights in this type of account also brings with it a welcome emphasis on the need for ongoing mobilisation to ensure that rights are defended and secure. This resonate with Foucault's assertion that it is 'not because there are laws, and not because I have rights, that I am entitled to defend myself...it is because I defend myself that my right exists and the law defends me' (Golder, 80).

On the whole, I think the term 'political' is preferable to the idea of rights being tactical with its implications of insincerity and even slipperiness. The idea of a tactical rights politics immediately 
raises some tricky questions: tactical for whom? And for which ends? What reason would others have to accept a merely tactical deployment of the discourse? It invariably raises the suspicion that the rights tactician is availing themselves of the normative vocabulary of humanism in the diagnosis of what is wrong, while refusing to be held responsible for any concrete normative position. The worry is that this evacuates rights politics of any principled basis without which it is unclear what genuine critical capacity it would have. Moreover, it raises the prospect that rights might be unevenly and hypocritically applied, so that political 'enemies' are condemned and 'allies' exculpated for their oppression, in a way that recalls some of the most vulgar forms of leftist thinking. Part of the strength of rights is that their enjoyment extends beyond whatever partisan bonds of attachment we might have.

Given the empirical fact of pluralism both across and within cultures, it may well be an advantage of rights and human rights that they are to some extent ambiguous about their foundations in political morality since this allows for the possibility of agreement on broad principles from the members of a heterogeneous society. However, insofar as it is suggested that rights do not need any justificatory foundation, then that is surely misleading. To argue meaningfully about rights, we do not need to assume some ghostly metaphysical system according to which statements about rights are objectively true or false according to natural facts built into the fabric of the universe. Yet there must be some epistemic criteria, some set of principles, to guide judgments. The notion that there be some truth to the matter - supported from within the world of human experience and values appears to be a necessary supposition for making a rights claim and for meaningful argumentation to take place (see Waldron, 2004).

Here, the idea of moral 'truth' - or, if that sounds too top-down, of 'validity' - functions as epistemological ideal that regulates the whole enterprise. It allows us to assess whether a claimed right to ' $\mathrm{x}$ ' deserves authoritative recognition as a legal or conventional right to $\mathrm{x}$. In such contests, political agents conduct themselves as if a definitive case for the existence of a right can be established through a process of ongoing argumentation, while accepting that no single interpretation is fixed beyond possible future contestation. Foucault's own claim of a 'right of the governed', for example, would seems to express the idea that individuals have a right to determine how power is exercised in international politics; a claim, presumably, that transcends particular cultures, histories and traditions. If we were to dig a little deeper and ask why it is that it is human beings specifically - and not dogs, trees or rocks - that have such a right then there would presumably be some reference to the universal capacities of human beings as rational agents 
capable of deliberating and acting politically along with some kind of normative claim about why they are entitled to do so.

As I see it, the genealogical method can contribute to this process of democratic claim-making by first shaking us out of our complacent attachment to the superiority of a certain set of values and assumptions - a certain mode of being and acting - on the basis of its inherited status. Seeing rights as political, in the way I have described, accords with the concern of Foucault and his followers that the specification of a universal ideal should not impose a homogenous idea of human beings and suppress diversity; that it should not become a justification for social hierarchy, placing implicit limits on the kinds of freedom that are possible in future. At the same time, it avoids the unwelcome implication that we have no proper way of discriminating between different rights claims, making rights akin to unlegitimated moves in a rhetorical battle.

\section{The new human rights sceptics}

As human rights rose to international prominence in the decades following Foucault's death, climaxing in the apparent eclipse of revolutionary alternatives with the downfall of Soviet communism, a number of theorists began to apply his approach much more systematically to the critique of human rights discourse. There is now an extensive contemporary literature that combines Foucault's insights with a Marxist critique of political economy to identify the role human rights play in contemporary strategies of power and ideological legitimation. In this literature, human rights stand charged with a variety of sins (some more plausible than the others), being variously identified as a universalist moral gloss for Western imperialism, a handmaiden to neoliberal capitalism and a toothless diversion from more radical, collectivist projects. This literature also comes replete with a somewhat alarming set of titles, including the 'The End of Human Rights', 'Against Human Rights, 'The most we can hope for'...human rights and the politics of fatalism' and 'The Human Right to Dominate' (Douzinas, 2000; Žižek, 2005; Brown, 2004; Perugini and Gordin 2015).

Among recent critics, the Italian theorist Agamben is one of the few who takes a comprehensive rejectionist position that disavows the idea of rights as such (1988). The greater number of contemporary critics would appear to stop short of this step. Like Foucault himself, they are most appropriately thought of as human rights sceptics, rather than rejectionists, calling attention to the hidden exclusions in human rights discourse, while also recognising their potentially emancipatory 
role. Thus, today's critics talk of the 'paradox' of rights as a discourse that has the potential to both empower subordinate groups to challenge the authorities and a discourse that legitimates the power of those same authorities and supports the status quo. Along with the critical legal scholar Costas Douzinas, the political theorist Wendy Brown has been one of the most influential of these critics, with a number of books and articles that aim to uncover the hidden dangers and in-built limitations of rights discourse (Brown, 2000; Douzinas, 2013).

In her early work, Brown argued against progressives in the US such as Catherine MacKinnon who were pushing for specific identity-based legal rights against oppression, arguing that such rights risked codifying the very subordinate identities being struggled against (1995). Gender-specific rights for women against sexual harassment, for example, may constitute women as especially vulnerable and in need of protection based on a heterosexual norm of femininity, while omitting other forms of social domination based on class and race. Following Foucault's analysis, the worry here is that subordinate groups would self-regulate by conforming to a set of behaviours and expectations that fit the acceptable form of their identity as established in prevailing legal categories. A similar approach has been applied by other authors to the analysis of disabled rights, indigenous rights and LGBT rights (Ivison and Patton, 2000; Butler 2011).

In response, some feminist scholars have argued that Brown over-states the dangers of this 'regulatory' dimension of legal discourse, especially by comparison to the undoubted benefits institutionalisation can bring (Schwartzman 2002). That said, the post-structuralist critique of identity-based rights undoubtedly points to an important dynamic. The granting of rights to previously excluded groups is rarely an unalloyed good accompanied as it is by a social expectation that those groups conform to established ways of being and acting. One need only think here of the queer critique of gay marriage as a form of assimilation to bourgeois, heterosexual norms to see that it captures something.

In her analysis of international human rights, Brown has pursued the characteristically Foucauldian thought that the purportedly universal category of 'human beings' masks a malleable type of human subject amenable to prevailing systems of power. As with other sceptics, there is an unacknowledged tension in how the process of subjectification is said to operate. In some cases, this human figure is identified as a passive suffering object of pity - a depoliticised victim of starvation, violence and displacement. In other contexts, human rights configure individuals as assertive, selfreliant economic agents in keeping with CB MacPherson's analysis of the 'possessive individualism' of natural rights theory (2010). If any interpretation predominates, it is the latter. In 
their official form, human rights configure individuals as market actors with a set of minimal 'negative' rights to economic participation, smoothing the institutional and social terrain for the worldwide diffusion of market norms (Brown, 2004, p. 457). To this picture, Brown adds the classic Marxist concern that a system of formal egalitarian rights can obscures substantive inequalities of wealth and power and divert attention from broad structural questions.

While Brown and her fellow sceptics provide a convincing case that human rights by themselves are insufficient to challenge neoliberalism, they have had more difficulty in demonstrating that human rights play a central role in sustaining and promoting it. Notably, the modern regime of human rights contains a number of social rights to housing, healthcare and other material goods, that were not present in the more libertarian ideology of natural rights that Marx criticised. Most activists in human rights movements today are focused on resistance to political persecution, rather than on the protection of private property. As the historian Samuel Moyn pointed out, we should not mistake the chronological coincidence of the rights of human rights and the rise neoliberalism for a relationship of causation in the absence of a stronger explanatory link (2014, p. 147). To see the ascendancy of human rights as responsible for the lack of collective emancipatory projects may be confusing cause with effect.

\section{Liberalism in retreat?}

In 'Undoing the Demos', Brown focuses on neoliberalism much more directly with the aim of showing how contemporary neoliberal rule is reconsituting earlier liberal ideas of active citizenship and the common good. Following Foucault, her approach treats neoliberalism not as an economic or political ideology, specifying a particular relationship of the state to the market, but as an 'order of normative reason' which requires the extension of the market model into every domain of social life (even where money is not at stake) (30). The problem she identifies is not simply that neoliberalism generates inequality; that it corrupts social values with market logic; that it strengthens the political rule of a narrow oligarchic elite or that it generates endless crises and disruption. The problem is that neoliberalism colonises the very territory of politics on which these developments might be resisted, undermining the possibility of political subjecthood and reshaping the norms and values of democracy in economic terms.

Whereas classical economic liberalism gave us a vision of individuals as creatures of exchange (the 'truck, barter and exchange' of Adam Smith), neoliberalism promotes a conception of individuals - 
and states - as competitively driven agents in the manner of firms. Under neoliberalism, Brown argues, we are required to see ourselves as human capital, improving our competitive position in relation to others and managing our brand through an endless array of rankings and metrics that are now a ubiquitous feature of our everyday experience thanks to digital technology and social networks. Our highest drives have been reduced to economic-like processes, so that even one's dating life is approached in terms of investments and returns. As Brown ably shows, in Chapter 4, neoliberal political rationality makes what should be seen as matters of collective interest - such as clean water, mental health, education and personal security - matters of individual concern through processes of 'responsibilisation' (Brown 2015, p. 105).

The election of the Republican property tycoon Donald Trump to the US Presidency is the most crass and potentially dangerous manifestation of this corporate take-over to date. Trump and other senior figures in his administration talk of politics in the language of 'deals' and explicitly state that the government is a company and should be ran as such. Whereas some liberals regard this development as an aberration, Brown's analysis (written during the Obama years) allows us to see how it follows closely from the logic of previous administrations on both the Republican and Democratic side. Even in his most radical moments in office, Obama did not challenge the state-asfirm model. In his 'State of the Union' speech of 2013, which was celebrated for its return for the optimism of 'Hope and Change', Brown notes how Obama talked of a variety of progressive causes all in terms of their contribution to economic competitiveness. Even measures to stop domestic violence and prevent the ecological destruction of the planet had to be framed in terms of growth and market positioning (24-25).

Brown is most effective when unpicking the terminology and presuppositions of political discourse. In a powerful analysis of a number of recent judicial decisions, she shows how the courts have resorted to the legitimating value of economic terminology. In Citizens United in 2010, the Supreme Court notoriously ruled that corporate donations to political parties were a protected form of free speech. For Brown, the problem with this decision is not merely that corporations were treated as persons, but that speech itself was reconfigured as a form of investment. Under this depoliticised vision of the public realm, the animating ideals of democracy are no longer deliberation, political equality and the common good, but the unrestricted flow of information underpinned by the conception of the public sphere as a 'marketplace of ideas' (159). Notably, for Brown, neoliberalism differs from earlier forms of capitalism in eschewing talk of a natural right to property in favour of the language of competition and efficiency. While this is ostensibly a more 
normatively neutral vision, the resulting inequalities between 'winners' and 'losers' are assumed to be a matter of desert.

While she draws on Foucault's approach in the diagnosis of the problem, Brown seeks to add an account of how individuals as democratic subjects - 'homo politicus' - figure within liberal discourse. A perennial limitation of Foucault's perspective, she says, is that subjects 'resist being governed as individual subjects or as disciplinary bodies', rather than as a democratic collectivity (73). In one passage, Brown notes the 'unimpeachable virtue of civil and political rights as instruments of resistance against discrimination and state power', though she adds that this also 'obscures their own subversion by economisation' (167). Brown remains concerned that legal rights abstract from inequalities between speakers and lend a subtle veneer of legitimacy to corporate power. Yet the regime of liberal rights now figures less as a potentially sinister mode of domination than as something we stand to lose under neoliberal rule. The problem is less with liberal citizenship, but the subversion of the democratic identities that ought to guide it by the figure of 'homo economicus'.

Although Brown does not aim to provide a normative account of rights and democracy in this work, on some level the argument must be that corporate control of the political process is to be condemned because it undermines the rights of others to political equality. Her analysis has a dialectical flavour to it which echoes the writings of Claude Lefort, Etienne Balibar and other 'postMarxist' authors for whom liberalism's abstract norms of liberty and equality invariably mask exclusions, but are also a site of ongoing contestation (Balibar, 1988; Lefort, 1986). Rather than being dismissed as individualistic, political rights are understood here to have a collective democratic character. As Claude Lefort put it, 'the right of one individual to speak, to write, to print freely, implies the right of another to hear, to read, to keep and pass on the material printed' (1986). Under this reading, the abstract formalism of liberal citizenship leaves important inequalities unchecked, but it also enshrines freedoms to organise, protest, interrogate and criticise power that empower political subjects to articulate, publicise and challenge these exclusions.

As Brown puts it, 'liberal democracy's divide between formal principles and concrete existence provides the scene of paradox, contradiction, and at times, even catachresis that social movements of every kind have exploited for more than three centuries' (206). This emphasis on the productive paradoxes of political liberalism, over its in-built exclusions, most likely reflects the historical juncture we are currently face rather than any fundamental shift in her thinking. The gains of the new social movements in the 1970's and 1980's - which formed the context to Brown's earlier 
critique of identity-based rights - have now been assimilated into what Nancy Fraser terms the 'progressive neoliberalism' of Obama and the Clintons which adds a veneer of 'diversity' to increasing precarity and class inequality (2017).

The main challenge today is no longer simply that of progressive movements defining and struggling for new rights, but the defence of traditional liberal norms against the total neoliberal evisceration of the public sphere. In this regard, one important element missing from Brown's analysis is some account of the constellation of interests who stand to benefit from neoliberalism's colonisation of social and political life. As with Foucault's own writings, we sometimes seem to be given a picture of a social system operating independently of the actions of any particular agents an analysis of power without the powerful. Neoliberalism thus sometimes appears as an entirely autonomous force with its own drives, desires and aspirations. Here, it would have helped to link the analysis to contemporary social science studies on the 'oligarchic' takeover of the democratic process and the role of the corporate tech giants of Silicon Valley in transforming the democratic public sphere into a realm of profit (Winters, 2011; Givens and Page 2014; McChesney, 2013). Crucial to the revitalised democratic politics Brown hopes for will be some identification of who the adversary is to be confronted.

\section{Conclusion}

In response to the work of critique, some liberals seem to imply that the very project of highlighting the exclusions, limitations and hypocrisies of prevailing liberal categories must ultimately entail some form of deep anti-humanism. Yet both Foucault (in Golder's reading) and Brown demonstrate that it is possible to maintain a productive scepticism towards rights and other humanistic social categories while acknowledging their indispensable value in confronting relations of power in certain contexts. Golder's work provides a convincing case for recognising the basic continuities in Foucault's thought which highlights some original aspects of a 'tactical' approach to rights even where it fails to convince on the viability of a fully-fledged anti-foundationalism. Brown's work builds on Foucault in important ways to call attention to what we stand to lose politically through the unchecked expansion of neoliberal processes, vocabularies and modes of governance. Ultimately, the individualistic discourse of rights alone may be insufficient to provide the collective democratic challenge required to break with neoliberalism and challenge the emerging threat of authoritarian nationalism. Yet liberal citizenship nonetheless instantiates the idea that the state should be accountable to its citizens and bound to the common good, providing a space to identify injustices, formulate political alternatives and mobilise support for them. The challenge, it would 
seem, is to defend this civic identity without becoming captive to it; maintaining a sense of openness to new contestations. In this way, the disenfranchised demos can become the engine of a truer and more authentic universalism, extending and deepening the underlying egalitarian commitments of democratic institutions in new and unforeseen ways.

\section{Bibliography}

Agamben, Giorgio. "Homo Sacer: Sovereign Power and Bare Life." Trans. Daniel Heller-Roazen. Palo Alto: Stanford up (1998): 3-18.

Balibar, Etienne. "Propositions on citizenship." Ethics 98.4 (1988): 723-730.

Beitz, Charles R. The idea of human rights. Oxford University Press, 2011.

Brown, Wendy, States of injury: Power and freedom in late modernity, (1995).

- $\quad$ “"The Most We Can Hope For...": Human Rights and the Politics of Fatalism." The South Atlantic Quarterly 103.2 (2004).

- $\quad$ "Suffering rights as paradoxes." Constellations 7.2 (2000): 208-229.

Butler, Judith. Gender trouble: Feminism and the subversion of identity. Routledge, 2011.

Douzinas, Costas. The End of Human Rights. Hart Publishing (UK), 2000.

- $\quad$ "The paradoxes of human rights." Constellations 20.1 (2013): 51-67.

Dworkin, Ronald, et al. "Assisted suicide: the philosophers' brief." The New York Review of Books (1997): 41-47.

Finnis, John. Natural law and natural rights. (Oxford University Press, 2011). 
Foucault, Michel. Power/knowledge: Selected interviews and other writings, 1972-1977. Pantheon, 1980.

- “Confronting Governments: Human Rights,” Essential Works of Foucault 1954-1984, Volume 3: Power." (2000).

- $\quad$ Discipline \& punish: The birth of the prison. Vintage, 2012.

Fraser, Nancy. Unruly practices: Power, discourse, and gender in contemporary social theory. U of Minnesota Press, 1989.

Gewirth, Alan. Human rights: Essays on justification and applications. Chicago: University of Chicago Press, 1982.

Gilens, Martin, and Benjamin I. Page. "Testing theories of American politics: Elites, interest groups, and average citizens." Perspectives on Politics 12.03 (2014): 564-58

Ingram, James D. "What is a" right to have rights"? Three images of the politics of human rights." American Political Science Review (2008): 401-416.

Ishay, Micheline. The history of human rights: From ancient times to the globalization era. Univ of California Press, 2008.

Ivison, Duncan, and Paul Patton. Political theory and the rights of indigenous peoples. Cambridge University Press, 2000.

Lefort, Claude, The Political Forms of Modern Society: Bureaucracy, Democracy, Totalitarianism (MIT Press, 1986), 257.

Macpherson, Crawford Brough. The political theory of possessive individualism: Hobbes to Locke (2010).

McChesney, Robert W. Digital disconnect: How capitalism is turning the Internet against democracy. New Press, The, 2013. 
Moyn, Samuel. "A powerless companion: human rights in the age of neoliberalism." Law \& Contemp. Probs. 77 (2014): 147.

Paras, E. Foucault 2.0: Beyond Power and Knowledge (New York, 2006).

Patton, Paul. "Foucault, critique and rights." Critical Horizons 6.1 (2005): 267-287.

Perugini, Nicola, and Neve Gordon, The human right to dominate, Oxford University Press, 2015.

Rancière, Jacques, Dissensus: On politics and aesthetics. (Bloomsbury Publishing, 2015).

Schwartzman, Lisa H. "Feminist Analyses of Oppression and the Discourse of "Rights": A Response to Wendy Brown." Social theory and practice 28.3 (2002): 465-480.

Valentini, Laura. "In what sense are human rights political? A preliminary exploration." Political studies 60.1 (2012): 180-194.

Waldron, Jeremy. "The Rule of Law as a Theater of Debate" in Ronald Dworkin \& Justine Burley (eds.), Dworkin and His Critics: With Replies by Dworkin, Blackwell. pp. 319--336 (2004)

Wolin, Richard. "Foucault the neohumanist?." Chronicle of Higher Education 1 (2006).

Winters, Jeffrey A. Oligarchy. (John Wiley \& Sons, Ltd, 2011).

Žižek, Slavoj. "Against human rights." Wronging Rights?” Philosophical Challenges to Human Rights (2005). 